\title{
Correction to: Guest Editors' Introduction to the Special Issue, "Jewish (In) Visibility in Iberia: A View from the Margins"
}

\section{Silvina Schammah Gesser ${ }^{1,2}$ (i) $\cdot$ Teresa Pinheiro $^{3}$ (])}

Published online: 20 July 2021

(C) Springer Nature B.V. 2021

\section{Correction to: Contemporary Jewry https://doi.org/10.1007/s12397-021-09359-1}

Please note: The guest editors' introduction refers to an article by Yitzchak Kerem which could not be included at this time in the special issue. The article may appear in a later issue of Contemporary Jewry.

Publisher's Note Springer Nature remains neutral with regard to jurisdictional claims in published maps and institutional affiliations.

The original article can be found online at https://doi.org/10.1007/s12397-021-09359-1.

Silvina Schammah Gesser

silvina.gesser@mail.huji.ac.il

Teresa Pinheiro

teresa.pinheiro@phil.tu-chemnitz.de

1 Salti Institute for Ladino Studies, Bar Ilan University, Ramat Gan, Israel

2 Truman Institute, Hebrew University of Jerusalem, Jerusalem, Israel

3 Institute for European Studies, Chemnitz University of Technology, Chemnitz, Germany 